\title{
New perspectives in hydrogenase direct electrochemistry
}

\author{
Matteo Sensi, Melisa del Barrio, Carole Baffert, Vincent Fourmond and \\ Christophe Léger ${ }^{\star}$ \\ Laboratoire de Bioénergétique et Ingénierie des Protéines, Aix Marseille Univ, CNRS, \\ UMR7281, Marseille, France. \\ bip06.fr, @BIP6_Marseille, leger@imm.cnrs.fr
}

\begin{abstract}
Electrochemical studies of hydrogenases, the biological catalysts of $\mathrm{H}_{2}$ oxidation and production, have proven wrong the old saying that enzymes do not easily transfer electrons to electrodes in the absence of mediators. Many distinct hydrogenases have actually been directly connected to electrodes or particles, for studying their catalytic mechanism or for designing solar fuels catalysts. In this review, we list the electrodes that have proved successful for direct electron transfer to hydrogenases, and we discuss recent results which illustrate new directions in this research field: the study of the biosynthesis of FeFe hydrogenase, the electrochemical characterization of non-standard $\mathrm{NiFe}$ - or FeFe hydrogenases, the general discussion of what makes a catalyst better in one particular direction of the reaction, and the elucidation of the molecular mechanism of hydrogenase catalysis by combining electrochemistry and theoretical chemistry, spectroscopy or photochemistry. The electrochemical methods described herein will probably prove useful for studying or using other redox enzymes.
\end{abstract}

\section{Introduction}

$2 \quad$ Hydrogenases are the enzymes that oxidize and produce $\mathrm{H}_{2}$. They are 3 classified as NiFe- and FeFe-hydrogenases based on the metal content of their by the sulfur atoms of two cysteine residues; the $\mathrm{Ni}$ ion is also attached to the protein by either two cysteines or one cysteine and one selenocysteine. 


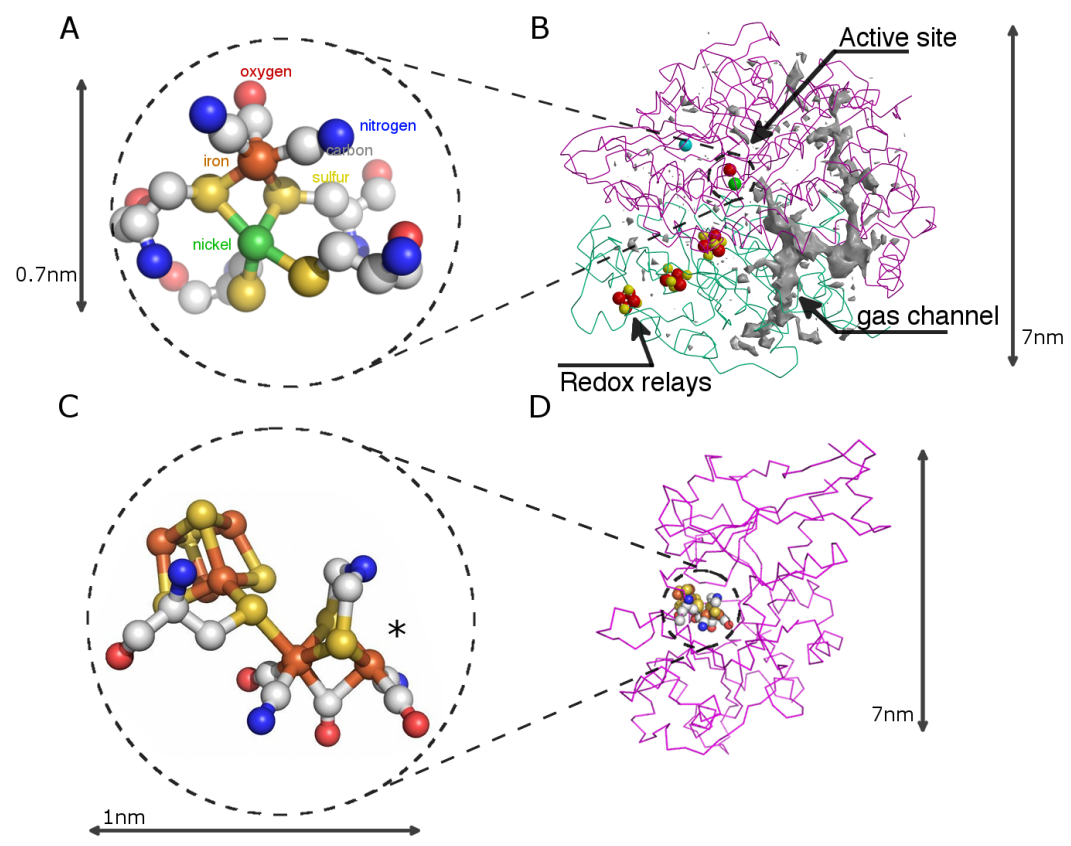

Figure 1: The X-ray structures of two hydrogenases. Panel A shows the active site of NiFe hydrogenases. Panel B shows the backbones of the heterodimeric enzyme from $D$. fructosovorans (pdb 1YQW). Panel C shows the $\mathrm{H}$ cluster of FeFe hydrogenases (a star marks the $\mathrm{H}_{2}$ binding site), and panel D shows the backbone of the enzyme from Chlamydomonas reinhardtii (pdf 3LX4).

The Fe ion binds carbonyl and cyanide ligands which also occur at the active site of FeFe hydrogenases, the "H cluster", shown in fig $1 \mathrm{C}$.

The NiFe hydrogenases that have been crystallized so far all look like the heterodimeric enzyme from $D$. fructosovorans, whose structure is shown in fig 1B. A chain of three FeS clusters (whose exact nature varies) wires the active site to the soluble redox partner or the electrode. The FeFe hydrogenase from C. reinhardtii whose structure is shown in fig $1 \mathrm{D}$ has no other cofactor than the surface-exposed $\mathrm{H}$ cluster, but other FeFe hydrogenases embed accessory FeS clusters for long range electron transfer (ET).

Evidence for direct electron transfer between electrodes and hydrogenases goes all the way back to the 1980's [10, 35, 71], and the research in this field has expanded enormously over the last ten years, driven by the objective of using hydrogenases in solar-fuels devices. When direct electrochemistry is 
used in the context of enzyme kinetics, it provides unequalled redox control, time resolution and accuracy of the activity measurement, together with flexibility in terms of transient exposures to inhibitors and/or substrate. If such kinetic information is combined with that obtained from other methods, the potential for gaining original information becomes enormous.

\section{Electrodes for direct electron transfer}

Hydrogenases are easily wired to electrodes because they all have at least one surface-exposed redox center, either the active site (e.g. fig 1D) or the final redox relay (e.g. fig 1B), which allows fast electron entry/exit. (This is unlike other redox enzymes such as glucose oxidase where the active site is buried and isolated in the protein matrix.) Many hydrogenases oxidize and produce hydrogen at very high rates (in excess of thousands per second, table 4 in ref [75]), and therefore a catalytic current may be detected even if the amount of enzyme that is attached to the electrode is very low. This explains the diversity of electrode materials that have proven useful in this context, listed in table 1 (see also refs [76 78] for reviews). Finely designed architectures for embedding membrane-bound hydrogenases have also been developed 799 81].

\section{Heterogeneous reconstitution}

In the natural biosynthetic pathway of $\mathrm{FeFe}$ hydrogenase, a $2 \mathrm{Fe}$ fragment of the $\mathrm{H}$ cluster is delivered to the "apo" form of the enzyme. The recent discovery that a synthetic $2 \mathrm{Fe}$ fragment can be incorporated into apohydrogenase has revolutionized hydrogenase research [82, 83]. The use of direct electrochemistry to probe the kinetics of such artificial maturation of the enzyme is one of the most recent and exciting developments: the apoenzyme can be adsorbed onto an electrode and can incorporate the $2 \mathrm{Fe}$ synthetic subcluster when the latter is added to the solution. The reconstitution of a holo-active enzyme results in an increase in $\mathrm{H}_{2}$-oxidation current which reports on the rate of reconstitution [84]. (This is reminiscent of the recent evidence by Limoges and coworkers that the PQQ cofactor of glucose dehydrogenase can bind the apo-enzyme anchored on an electrode surface [85].) Armstrong and coworkers could design potential-steps PFV experiments to detect the formation of an intermediate that is probably relevant to the final stage of biological $\mathrm{H}$ cluster maturation. 


\section{Electrochemical studies of exotic hydrogenases}

The electrochemical literature does not accurately reflect the biodiversity of hydrogenases. Indeed, most of the hydrogenases that have been studied in electrochemistry are very similar to each other. They are relatively small (60-100 kDa), and consist of a small number of proteins subunits, most often one or two. In contrast, some hydrogenases are part of very large enzymatic systems (e.g. 18 subunits and $600 \mathrm{kDa}$ in the formate hydrogene lyase complex of Thermococcus). These complex hydrogenases use the same active sites as those shown in fig 1 , but their protein sequences, quaternary structure and cofactor content make them unique.

Recent electrochemical studies of hydrogenases whose structures are out of the ordinary [19, 22, 23, 73] have revealed unprecedented properties. For example, the NiFe hydrogenase of the hyperthermophilic bacterium $P$. furiosus remains active upon exposure to $\mathrm{O}_{2}$ at $80^{\circ} \mathrm{C}$, and its mechanism of $\mathrm{O}_{2}$ tolerance is uncommon [23]. The FeFe hydrogenase of $A$. woodii is part of a large complex which reduces $\mathrm{CO}_{2}$ to formate; it has high affinity for $\mathrm{H}_{2}$ and is reversibly inhibited by $\mathrm{CO}$ under all redox conditions [73], unlike other FeFe hydrogenases, for which the inhibition is only partly reversible under reducing conditions [70].

Together with site-directed mutagenesis studies, the characterization of these non-standard hydrogenases demonstrates that the catalytic properties depend on the environment of the active site, but also on structural elements that are remote from the conserved active site.

\section{The catalytic bias}

Studies of hydrogenases have recently encouraged discussions on an important and often neglected aspect of enzyme catalysis: the question of what makes a particular enzyme a better catalyst in one direction of the reaction than in the other [91]. Answering this question is very important in the context of solar fuels research, for the rational design of either synthetic catalysts [92] or bacterial strains [93] that either produce or oxidize $\mathrm{H}_{2}$.

One defines the catalytic bias of a hydrogenase as the ratio of the $\mathrm{H}_{2}$ oxidation and $\mathrm{H}_{2}$ production rates, which have to be measured under two different sets of experimental conditions. In PFV experiments, sweeping the potential makes it possible to probe the enzymatic response on either side of the equilibrium potential (OCP) in a single experiment. Any predisposition 

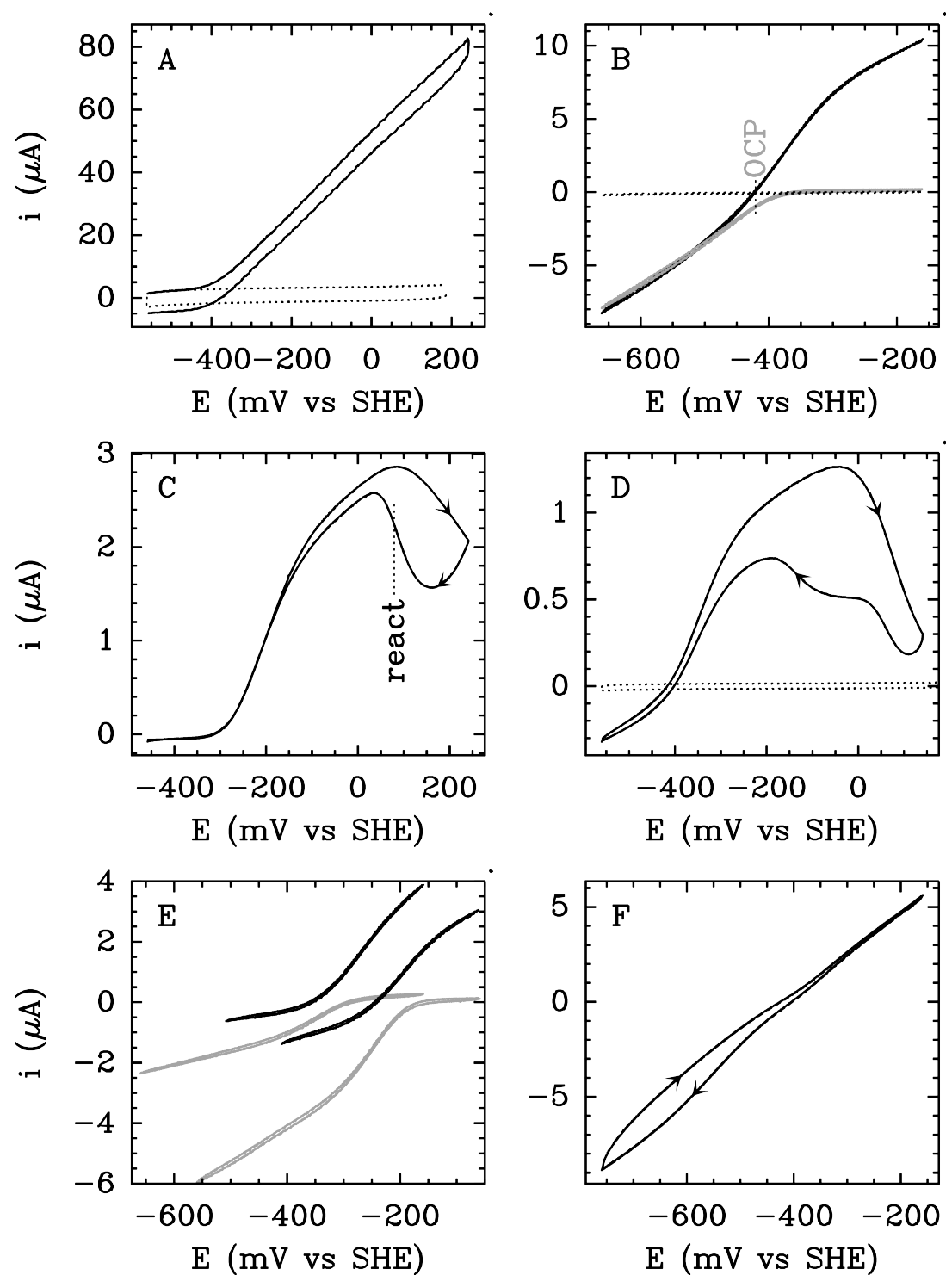

Figure 2: Cyclic voltammograms obtained with hydrogenases undergoing direct ET with a rotating electrode, recorded under an atmosphere of either $\mathrm{N}_{2}$ (gray lines) or $\mathrm{H}_{2}$ (black lines). The oxydation current is counted as positive. Arrows mark the directions of the potential sweeps. The dotted lines are blanks. A: $\mathrm{H}_{2}$ oxidation by $A$. vinosum $\mathrm{NiFe}$ hydrogenase (the fast scan rate used here prevents oxidative inactivation) [86]. B: $\mathrm{H}_{2}$ oxidation and evolution by $C$. acetobutilicum FeFe hydrogenase [53]. C: high potential inactivation of $A$. aeolicus NiFe hydrogenase [25]. D: high potential inactivation of a sitedirected mutant of $C$. reinhardtii $\mathrm{FeFe}$ hydrogenase [56]. E: $\mathrm{H}_{2}$ oxidation and evolution by $D$. fructosovorans $\mathrm{NiFe}$ hydrogenase at $\mathrm{pH} 4$ or 6 (signals at higher or lower potential, respectively), all other things being equal [87]. F: low potential reversible inactivation of C. reinhardtii $\mathrm{FeFe}$ hydrogenase at $\mathrm{pH} 7$ [88]. In all cases here, the absence of current plateau results from the distribution of interfacial ET rate constants [86, 89, 90. 
for oxidizing or producing $\mathrm{H}_{2}$ is thus qualitatively observed as a larger current in one particular direction (fig 2) [94]. (Of course, the rate of $\mathrm{H}_{2}$ evolution is likely to be larger under more acidic conditions because the proton is the substrate [87, 95], and $\mathrm{H}_{2}$ production is also faster when $\mathrm{H}_{2}$ is removed 95, 96]; see fig 2E.)

A standardized method for measuring the bias (either in solution assays or on an electrode) is lacking, but the comparison between various results such as those in fig. 2 suggested that NiFeSe [43, 44, 100, and FeFe hydrogenases are better $\mathrm{H}_{2}$-production catalysts than their $\mathrm{NiFe}$ counterparts (see however ref [22]). The $\mathrm{O}_{2}$-resistant NiFe hydrogenases are essentially unidirectional $\mathrm{H}_{2}$-oxidation enzymes whereas the standard $\left(\mathrm{O}_{2}\right.$-sensitive $)$ enzymes are bidirectional catalysts [101, and certain mutations that strongly increase the $\mathrm{O}_{2}$-tolerance of standard $\mathrm{NiFe}$ hydrogenase also selectively slow $\mathrm{H}_{2}$-evolution [12, 102 104. Other mutations of amino acids that are remote from the active site also alter the bias of NiFe hydrogenases [105 107].

There is much interest in understanding the bias in relation to the shape of the catalytic signal and the properties of the catalytic intermediates. The ratio of oxidative and reductive currents is inevitably related to the difference between the two-electron "catalytic potential" $E_{\text {cat }}$ and the OCP by eq. 1 in box 1 , but various models give distinct answers to the question of what defines $E_{\text {cat }}$. Emphasis was often on the role of the redox relays [89, 97, 107] (Box 1 ), but there is one clear example from our group where the bias is defined by the $\mathrm{H}_{2}$ diffusion rates along the gas channel [104].

The observed rate of catalysis in either direction is also affected by any redox-driven inactivation of the enzyme, unmistakably detected as a hysteresis in cyclic voltammetry at a rotating disc electrode (RDE) [90]. NiFe hydrogenases reversibly inactivate under oxidative conditions [12, 25, 43, 108], whereas FeFe hydrogenases inactivate in a complex manner both at high [56, 68, 73] and low potential [84, 88] (see e.g. figs 2C, D and F, respectively).

\section{Combining electrochemistry and theoretical chemistry}

(Electro)kinetic measurements alone most often cannot give the molecular mechanism of a reaction whose rate is being measured. An approach that has recently gained popularity is to combine electrochemistry and theoretical chemistry [109]. In this context, a seminal PFV paper addressed the mechanism of electron/proton transfer to a buried FeS cluster in a small 
protein [110]: electrochemical experiments identified the "kinetic mechanism" (sequential, rather than concerted), and the results of molecular dynamics (MD) simulations and site-directed mutagenesis (SDM) experiments could be used to describe the molecular details of the reaction.

More recently, the approach that combines PFV and theoretical calculations (DFT and/or MD) proved powerful to decipher the mechanism of inhibition of FeFe hydrogenases by formaldehyde [111-113], $\mathrm{CO}$ [57, 70], $\mathrm{O}_{2}$ [57, or under anaerobic oxidative conditions [56]. These studies concern the active site mechanism, but also the diffusion along gas channels and binding at the active site of small molecules: the rates of these reactions can be measured using electrochemistry and sometimes calculated - this was achieved with both $\mathrm{NiFe}$ 55, 109, 114, 115] and FeFe hydrogenases [54, 57.

\section{Direct spectroelectrochemistry}

The vibrations of the carbonyl and cyanide ligands at the active sites of hydrogenases result from IR absorptions in the $1800-2100 \mathrm{~cm}^{-1}$ region, which is devoid of other absorption bands, allowing selective detection of the active site. Spectroelectrochemical titrations followed by FTIR spectroscopy have identified various states of the active sites, some of which are probably catalytic intermediates. The caveat of this approach is that a system that reduces protons can only reach equilibrium under a certain pressure of hydrogen that becomes much too large at potentials below $E^{0 \prime}=-0.06 \times \mathrm{pH}$. For instance, equilibration at $-450 \mathrm{mV}$ at $\mathrm{pH} 7$ requires a $\mathrm{H}_{2}$ pressure of 10 bars, much too high for a spectroelectrochemical cell to withstand. Recently, various groups have gone beyond equilibrium titrations by combining standard catalytic protein film voltammetry with the simultaneous detection of the active site spectroscopic signatures of NiFe hydrogenases; this made it possible to correlate the features of the catalytic response and specific states of the active site, as illustrated below.

Surface-enhanced infra-red absorption spectroscopy, with NiFe hydrogenases adsorbed onto modified gold electrodes, has been used to relate the appearance of the $\mathrm{NiB}$ active site signature to the disappearance of activity at high potentials [116, 117].

A significant breakthrough came from the Vincent group in Oxford, who combined an attenuated total reflection cell with a volumic carbon black electrode [118], giving electrochemical signals strongly resembling those obtained with a "flat" PGE electrode, with enough sensitivity to characterize species 
that had previously escaped detection. Vincent and coworkers showed that the Ni-L state, long thought to be an artifact of illumination at cryogenic temperatures, is one of the possible intermediates of the oxidation of $\mathrm{Ni}-\mathrm{C}$ [32], with which it is in acid-base equilibrium [119]. They could also detect for the first time the presence of $\mathrm{Ni}-\mathrm{R}$, the most reduced state in the catalytic cycle, in $R$. eutropha regulatory hydrogenase [120].

\section{Direct photoelectrochemistry}

The active sites of hydrogenases bearing Fe-carbonyl bonds, it is no surprise that these enzymes are sensitive to light in the UV-vis range. It has long been know that exposure to white light reactivates the FeFe hydrogenase bound to extrinsic $\mathrm{CO}$, but until recently the photochemistry of hydrogenases was much less studied than that of hydrogenase synthetic mimics.

In spectroscopic investigations, information on the electronic structure of the active site is obtained from the knowledge of which wavelengths are absorbed by the cluster; in contrast, with the enzyme wired to an electrode, one can detect light absorption by monitoring wavelength-dependent lightinduced changes in turnover rate. This is possible even when the protein or chromophores hide the weak absorption that triggers the change in activity. By monitoring changes in turnover rate, one is certain to focus on light absorption events that impact the catalytic intermediates.

Regarding FeFe hydrogenases, the first direct photoelectrochemistry experiments focused on the inhibited form of the active site and the enhancement of the rate of release of extrinsic CO by white light 68. More recently, we could observe that this enhancement only occurs in the blue part of the visible spectrum, and it is proportional to light power; the effect is small because the $\mathrm{H}$ cluster has very low absorption in the visible range, but the quantitative analysis of the electrochemical data demonstrates that every photon that is absorbed by the inhibited $\mathrm{H}$ cluster induces $\mathrm{CO}$ release [72].

It had also been reported that day-light destroys the $\mathrm{H}$ cluster of $D$. desulfuricans FeFe hydrogenase [121], which certainly raises questions as to whether FeFe hydrogenases can be coupled to photosensitizers for solar $\mathrm{H}_{2}$ production. White light photo-electrochemistry experiments with $D$. desulfuricans $\mathrm{FeFe}$ hydrogenase gave a less dramatic picture [122]. In the case of the enzymes from $C$. acetobutylicum and $C$. reinhardtii, recent results demonstrate that photoinhibition only occurs upon UV irradiation, which triggers 
the release of an intrinsic CO ligand followed by irreversible isomerisation of the $\mathrm{H}$ cluster [123].

Lojou and coworkers also discovered that irradiation at $405 \mathrm{~nm}$ activates the $\mathrm{O}_{2}$-tolerant $\mathrm{NiFe}$ hydrogenase from $A$. aeolicus under turnover conditions [124. The mechanism and action spectrum of this unprecedented reaction and the implications regarding the nature of the inactive states of $\mathrm{NiFe}$ hydrogenases must be explored.

\section{Conclusion}

The abundant literature in the field of hydrogenase electrochemistry reflects the ease with which catalytic currents are obtained, the variety of the mechanistic questions that these studies can answer, the large number of applications which rely on wiring hydrogenases to electrodes, nanoparticles or photosensitizers [77, 125 128] and, of course, the creativity and combined talent of many biochemists and electrochemists. The implications of these results are wide, from the understanding of fundamental concepts in electrocatalysis to implications for the design of solar-fuel catalysts. We hope that they will also prove inspirational in other, related fields of research.

\section{Funding Source Declaration}

Our work is supported by CNRS, Aix Marseille Université, Agence Nationale de la Recherche (ANR-12-BS08-0014, ANR-14-CE05-0010, ANR-15CE05-0020), and Excellence Initiative of Aix-Marseille University - A*MIDEX, a French "Investissements d'Avenir" programme (ANR-11-IDEX-0001-02). The authors are part of the FrenchBIC network (www.frenchbic.cnrs.fr). 


\begin{tabular}{|c|c|c|}
\hline Type & Source & Attachement methods \\
\hline \multirow[t]{19}{*}{$\mathrm{NiFe}$} & A. vinosum & PGE/polymyxin [1, 2], Au/polymyxin [3, 4], PGP [5] \\
\hline & D. gigas & $\mathrm{Au} / \mathrm{SAM} / \mathrm{CDC}$ 6], GC [7], $\mathrm{PGE} / \mathrm{CDC}$ [8], \\
\hline & & $\mathrm{CNT} / \mathrm{CDC}[9]$ \\
\hline & D. vulgaris Hildenborough & PGE/polylysine [10, basal PGE [11] \\
\hline & D. fructosovorans & PGE [12, PGE/CDC 13, CNT 14] \\
\hline & E. $\operatorname{coli}(\mathrm{Hyd}-1)$ & PGE [15, pyrenyl carbon nanostructures [16 \\
\hline & E. $\operatorname{coli}(\mathrm{Hyd}-2)$ & PGE [17, PGP [18] \\
\hline & E. $\operatorname{coli}(\mathrm{Hyd}-3)$ & $\mathrm{PGE} / \mathrm{CNT} /$ polymixin 19 \\
\hline & E. coli membrane fractions & $\mathrm{TiO}_{2}$ \\
\hline & Citrobacter sp. S-77 & $\mathrm{CC} / \mathrm{CB}[21]$ \\
\hline & Synechocystis sp. PCC 6803 & PGE 22] \\
\hline & P. furiosus (hydrogenase I) & PGE 23] \\
\hline & A. aeolicus & PGB [24, PGE 25], Au/SAM [26], CNT 27], \\
\hline & R. eutropha (MbH) & PGE(FAA), AU/SAM 30, 31] \\
\hline & R. eutropha $(\mathrm{RH})$ & $\mathrm{CB}[32$ \\
\hline & R. metallidurans $\mathrm{CH} 34(\mathrm{Rm})$ & PGE 33 \\
\hline & R. eutropha (SH) & PGE 34 \\
\hline & T. roseopersicina & $\mathrm{CB}$ [35], CNT [36, CNF [37], CNF/MPDB 38] \\
\hline & H. marinus & $\mathrm{Au} / \mathrm{CDC}[39$, $\mathrm{GC} \& \mathrm{Gc} / \mathrm{KB}[40]$ \\
\hline \multirow[t]{2}{*}{$\mathrm{NiFeSe}$} & D. vulgaris Hildenborough & $\mathrm{Au} / \mathrm{SAM} / \mathrm{CDC}$ [6, 41, 42, PGE [43] \\
\hline & D. baculatum & PGE [44, $\mathrm{TiO}_{2} \mathrm{NP}$ [45], mesoporous $\mathrm{TiO}_{2}$ [46], $\mathrm{SiTiO}_{2}$,47] \\
\hline \multirow[t]{8}{*}{$\mathrm{FeFe}$} & C. acetobutylicum & $\mathrm{TiO}_{2}$ [48], CF [49], Au/SAM [50], CNT [51, 52], PGE [53 557], \\
\hline & & $\mathrm{PGE} / \mathrm{CDC}[5860$, CdS 61 63], \\
\hline & & CdTe NC 64, CdTe QD 65, bSi 66] \\
\hline & C. perfringens & $\mathrm{TiO}_{2}$ [67 \\
\hline & D. desulfuricans & PGE [54, 55, 68, PGE/CDC [59] \\
\hline & C. reinhardtii & $\mathrm{Au} / \mathrm{SAM}$ [69, PGE [54, 59, 70], PGE/CDC [58] \\
\hline & M. elsdenii & GC [71, PGE[72] \\
\hline & A. woodii & PGE 73 \\
\hline
\end{tabular}

Table 1: The hydrogenases that have been directly connected to electrodes, and the natures of the electrodes used in these studies. bSi: nanoporous black silicon CC/CB: carbon black on carbon cloth, CDC: carbodiimide coupling, CF: carbon felt, NC: nanocrystals, NP: nano-particles, GC: glassy carbon, GC/KB: Ketjen black-modified GC, CNT: carbon nanotubes, CNF: carbon nanofibers, MPDB: electropolymerized pyrrol, PGE: pyrolytic graphite edge [74, PGB: basal plane of PG, PGP: PG particles, QD: quantum dots, SAM: self assembled monolayers, 
If the steady-state catalytic wave shape is sigmoidal, as observed in the case of hydrogenases, a simple equation relates the two-electron "catalytic potential" $E_{\text {cat }}$, the open circuit potential (Nernst potential of the $\mathrm{H}^{+} / \mathrm{H}_{2}$ couple), and the catalytic bias:

$$
\frac{i_{\mathrm{ox}}}{i_{\text {red }}}=\exp \left[\frac{2 F}{R T}\left(E_{\text {cat }}-E_{\mathrm{OCP}}\right)\right]
$$

The value $n=2$ comes from the stoichiometry of the redox reaction, and eq. 1 results from the condition that $i=0$ at the OCP.

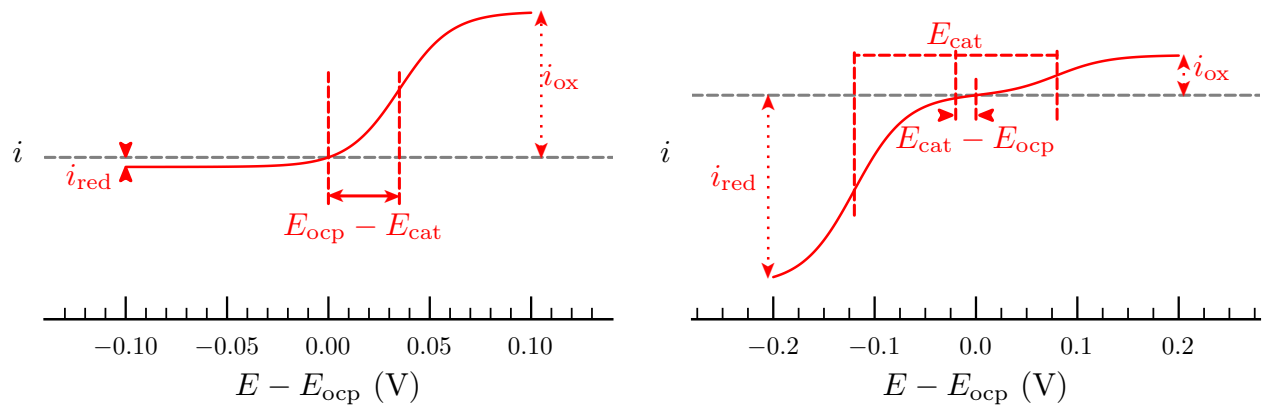

For a two-electron redox reaction, if the catalytic signal is a two-electron sigmoid (left panel), $E_{\text {cat }}$ in eq. 1 is the mid-wave potential; if the wave consists of two one-electron waves (right panel), $E_{\text {cat }}$ is the average value of the two mid-wave potentials. In intermediate cases or if the signal is broadened by slow interfacial ET, $E_{\text {cat }}$ must be determined by fitting [90]. Verifying eq 1 in a particular case does not give an explanation for the bias. What matters is the reason $E_{\text {cat }}$ takes a particular value. According to models that only take into account one relay (no active site, no redox chain, no kinetics of intramolecular ET), $E_{\text {cat }}$ can only equate the potential of the unique redox center in the model, the relay [97]; this was taken as evidence that the difference between the potential of the entry/exit relay and the OCP defines the catalytic bias [98]. In contrast, according to models that take into account reversible catalysis, one-electron mediation, and two-electron active-site chemistry, the two-electron potential $E_{\text {cat }}$ cannot strictly equate the one-electron potential of any of the redox relays [89]; $E_{\text {cat }}$ tends to the potential of the active site if intramolecular ET is very fast, but its value is influenced by the kinetics and thermodynamics of intramolecular ET, and the kinetics of all steps in the catalytic cycle that are coupled to active site redox chemistry [89, 90, 99].

Box 1: The relation between catalytie overpotential and the catalytic bias, when the catalytic signal is sigmoidal. 


\section{References}

[1] H. R. Pershad, J. L. Duff, H. A. Heering, E. C. Duin, S. P. Albracht, F. A. Armstrong, Catalytic electron transport in chromatium vinosum [NiFe]-hydrogenase: application of voltammetry in detecting redox-active centers and establishing that hydrogen oxidation is very fast even at potentials close to the reversible $\mathrm{H}^{+} / \mathrm{H}_{2}$ value., Biochemistry 38 (1999) 8992-8999. doi 10.1021/bi990108v.

[2] A. K. Jones, E. Sillery, S. P. J. Albracht, F. A. Armstrong, Direct comparison of the electrocatalytic oxidation of hydrogen by an enzyme and a platinum catalyst, Chem. Commun. (2002) 866-867. doi:10.1039/b201337a

[3] F. J. M. Hoeben, I. Heller, S. P. J. Albracht, C. Dekker, S. G. Lemay, H. A. Heering, Polymyxin-Coated au and carbon nanotube electrodes for stable [NiFe]-hydrogenase film voltammetry, Langmuir 24 (2008) 5925-5931. doi:10.1021/la703984z.

[4] F. J. M. Hoeben, F. S. Meijer, C. Dekker, S. P. J. Albracht, H. A. Heering, S. G. Lemay, Toward Single-Enzyme molecule electrochemistry: [NiFe]-hydrogenase protein film voltammetry at nanoelectrodes, ACS Nano 2 (2008) 2497-2504. doi $10.1021 / \mathrm{nn} 800518 \mathrm{~d}$.

[5] K. A. Vincent, X. Li, C. F. Blanford, N. A. Belsey, J. H. Weiner, F. A. Armstrong, Enzymatic catalysis on conducting graphite particles, Nat. Chem. Biol. 3 (2007) 761-762. doi $10.1038 /$ nchembio.2007.47.

[6] O. Rüdiger, C. Gutiérrez-Sánchez, D. Olea, I. A. Pereira, M. Vélez, V. M. Fernández, A. L. De Lacey, Enzymatic anodes for hydrogen fuel cells based on covalent attachment of Ni-Fe hydrogenases and direct electron transfer to SAM-modified gold electrodes, Electroanalysis 22 (2010) 776-783. doi 10.1002/elan.200880002.

[7] C. M. Cordas, I. Moura, J. J. G. Moura, Direct electrochemical study of the multiple redox centers of hydrogenase from desulfovibrio gigas, Bioelectrochemistry 74 (2008) 83-89. doi $10.1016 /$ j.bioelechem.2008.04.019.

[8] O. Rüdiger, J. M. Abad, E. C. Hatchikian, V. M. Fernandez, A. L. De Lacey, Oriented immobilization of Desulfovibrio gigas hydrogenase onto carbon electrodes by covalent bonds for nonmediated oxidation of $\mathrm{H}_{2}$, J. Am. Chem. Soc. 127 (2005) 16008-16009. doi $10.1021 /$ ja0554312.

-• The first paper showing covalent (hence long term) attachment of NiFe hydrogenase to a graphite electrode. This method proved useful later for quantifying the various inactive forms of the enzyme that are produced upon oxidative inactivation [13] and could be adapted to attach FeFe hydrogenase [58].

[9] M. A. Alonso-Lomillo, O. Rüdiger, A. Maroto-Valiente, M. Velez, I. RodríguezRamos, F. J. Muñoz, V. M. Fernández, A. L. De Lacey, Hydrogenase-Coated carbon nanotubes for efficient $\mathrm{H}_{2}$ oxidation, Nano Lett. 7 (2007) 1603-1608. doi:10.1021/ nl070519u. 
[10] P. Bianco, J. Haladjian, Electrocatalytic hydrogen evolution at the pyrolytic graphite electrode in the presence of hydrogenase, J. Electrochem. Soc. 139 (1992) $2428-2432$. doi $10.1149 / 1.2221244$.

[11] M. Guiral-Brugna, M. T. Giudici-Orticoni, M. Bruschi, P. Bianco, Electrocatalysis of the hydrogen production by [Fe] hydrogenase from Desulfovibrio vulgaris hildenborough, J. Electroanal. Chem. 510 (2001) 136-143. doi:10.1016/s0022-0728(01) 00502-2.

[12] A. A. Hamdan, P.-P. Liebgott, V. Fourmond, O. Gutiérrez-Sanz, A. L. De Lacey, P. Infossi, M. Rousset, S. Dementin, C. Léger, Relation between anaerobic inactivation and oxygen tolerance in a large series of NiFe hydrogenase mutants, Proc. Natl. Acad. Sc. USA 109 (2012) 19916-19921. doi:10.1073/pnas.1212258109.

[13] A. Abou Hamdan, B. Burlat, O. Gutiérrez-Sanz, P.-P. Liebgott, C. Baffert, A. L. De Lacey, M. Rousset, B. Guigliarelli, C. Léger, S. Dementin, $\mathrm{O}_{2}$-independent formation of the inactive states of NiFe hydrogenase, Nat. Chem. Biol. 9 (2012) 15-17. doi $10.1038 /$ nchembio. 1110.

[14] E. Lojou, X. Luo, M. Brugna, N. Candoni, S. Dementin, M. T. Giudici-Orticoni, Biocatalysts for fuel cells: efficient hydrogenase orientation for $\mathrm{H}_{2}$ oxidation at electrodes modified with carbon nanotubes, J. Biol. Inorg. Chem. 13 (2008) 1157-1167. doi:10.1007/s00775-008-0401-8.

[15] M. J. Lukey, M. M. Roessler, A. Parkin, R. M. Evans, R. A. Davies, O. Lenz, B. Friedrich, F. Sargent, F. A. Armstrong, Oxygen-Tolerant [NiFe]-hydrogenases: The individual and collective importance of supernumerary cysteines at the proximal Fe-S cluster, J. Am. Chem. Soc. 133 (2011) 16881-16892. doi 10.1021/ja205393w.

[16] S. Krishnan, F. A. Armstrong, Order-of-magnitude enhancement of an enzymatic hydrogen-air fuel cell based on pyrenyl carbon nanostructures, Chem. Sci. 3 (2012) 1015-1023. doi:10.1039/c2sc01103d.

[17] M. J. Lukey, A. Parkin, M. M. Roessler, B. J. Murphy, J. Harmer, T. Palmer, F. Sargent, F. A. Armstrong, How Escherichia coli is equipped to oxidize hydrogen under different redox conditions, J. Biol. Chem. 285 (2010) 3928-3938. doi:10.1074/ jbc.m109.067751.

[18] O. Lazarus, T. W. Woolerton, A. Parkin, M. J. Lukey, E. Reisner, J. Seravalli, E. Pierce, S. W. Ragsdale, F. Sargent, F. A. Armstrong, Water-Gas shift reaction catalyzed by redox enzymes on conducting graphite platelets, J. Am. Chem. Soc. 131 (2009) 14154-14155. doi $10.1021 /$ ja905797w.

[19] J. S. McDowall, B. J. Murphy, M. Haumann, T. Palmer, F. A. Armstrong, F. Sargent, Bacterial formate hydrogenlyase complex, Proc. Natl. Acad. Sc. USA 111 (2014) E3948-E3956. doi 10.1073/pnas.1407927111. 
[20] S. Schlicht, L. Assaud, M. Hansen, M. Licklederer, M. Bechelany, M. Perner, J. Bachmann, An electrochemically functional layer of hydrogenase extract on an electrode of large and tunable specific surface area, J. Mater. Chem. A 4 (2016) 6487-6494. doi $10.1039 /$ c6ta00392c

[21] T. Matsumoto, S. Eguchi, H. Nakai, T. Hibino, K.-S. Yoon, S. Ogo, $[\mathrm{NiFe}]$ hydrogenase from citrobacter sp. s-77 surpasses platinum as an electrode for $\mathrm{H}_{2}$ oxidation reaction, Angew. Chem. Int. Ed. 53 (2014) 8895-8898. doi:10.1002/ anie.201404701

[22] C. L. McIntosh, F. Germer, R. Schulz, J. Appel, A. K. Jones, The [NiFe]-hydrogenase of the cyanobacterium Synechocystis sp. PCC 6803 works bidirectionally with a bias to $\mathrm{H}_{2}$ production, J. Am. Chem. Soc. 133 (2011) 11308-11319. doi:10.1021/ ja203376y.

[23] P. Kwan, C. L. McIntosh, D. P. Jennings, R. C. Hopkins, S. K. Chandrayan, C.-H. H. Wu, M. W. Adams, A. K. Jones, The [NiFe]-hydrogenase of Pyrococcus furiosus exhibits a new type of oxygen tolerance., J. Am. Chem. Soc. 137 (2015) 13556-13565. doi $10.1021 /$ jacs . 5b07680.

-• Electrochemical characterization of an oxygen-tolerant, group 3, soluble, thermophilic [NiFe]-hydrogenase. The mechanism of oxygen resistance is shown to differ from that of group 1 enzymes.

[24] E. Lojou, M.-T. Giudici-Orticoni, P. Bianco, Hydrogenases from the hyperthermophilic bacterium Aquifex aeolicus: electrocatalysis of the hydrogen production/consumption reactions at carbon electrodes, J. Electroanal. Chem. 577 (2005) 79-86. doi $10.1016 / \mathrm{j} \cdot \mathrm{jelechem.2004.11.016}$

[25] V. Fourmond, P. Infossi, M.-T. Giudici-Orticoni, P. Bertrand, C. Léger, "Two-Step" chronoamperometric method for studying the anaerobic inactivation of an oxygen tolerant NiFe hydrogenase, J. Am. Chem. Soc. 132 (2010) 4848-4857. doi:10.1021/ ja910685j.

[26] A. Ciaccafava, P. Infossi, M. Ilbert, M. Guiral, S. Lecomte, M. T. Giudici-Orticoni, E. Lojou, Electrochemistry, AFM, and PM-IRRA spectroscopy of immobilized hydrogenase: Role of a hydrophobic helix in enzyme orientation for efficient $\mathrm{H}_{2}$ oxidation, Angew. Chem. Int. Ed. 51 (2012) 953-956. doi 10.1002/anie.201107053.

[27] X. Luo, M. Brugna, P. Tron-Infossi, M. Giudici-Orticoni, E. Lojou, Immobilization of the hyperthermophilic hydrogenase from Aquifex aeolicus bacterium onto gold and carbon nanotube electrodes for efficient $\mathrm{H}_{2}$ oxidation, J. Biol. Inorg. Chem. 14 (2009) 1275-1288. doi $10.1007 / \mathrm{s} 00775-009-0572-\mathrm{y}$.

[28] A. Poulpiquet, H. Marques-Knopf, V. Wernert, M. T. Giudici-Orticoni, R. Gadiou, E. Lojou, Carbon nanofiber mesoporous films: efficient platforms for bio-hydrogen oxidation in biofuel cells, Phys. Chem. Chem. Phys. 16 (2014) 1366-1378. doi:10. 1039/c3cp54631d. 
[29] A. Ciaccafava, A. De Poulpiquet, V. Techer, M. T. Giudici-Orticoni, S. Tingry, C. Innocent, E. Lojou, An innovative powerful and mediatorless $\mathrm{H} 2 / \mathrm{O} 2$ biofuel cell based on an outstanding bioanode, Electrochemistry Communications 23 (2012) 25-28. doi $10.1016 /$ j.elecom.2012.06.035.

[30] M. Sezer, S. Frielingsdorf, D. Millo, N. Heidary, T. Utesch, M.-A. Mroginski, B. Friedrich, P. Hildebrandt, I. Zebger, I. M. Weidinger, Role of the HoxZ subunit in the electron transfer pathway of the Membrane-Bound [NiFe]-hydrogenase from Ralstonia eutropha immobilized on electrodes, J. Phys. Chem. B 115 (2011) 10368-10374. doi 10.1021/jp204665r.

[31] N. Heidary, T. Utesch, M. Zerball, M. Horch, D. Millo, J. Fritsch, O. Lenz, R. von Klitzing, P. Hildebrandt, A. Fischer, M. A. Mroginski, I. Zebger, OrientationControlled electrocatalytic efficiency of an adsorbed Oxygen-Tolerant hydrogenase, PLOS ONE 10 (2015) e0143101+. doi 10.1371/journal.pone.0143101.

[32] R. Hidalgo, P. A. Ash, A. J. Healy, K. A. Vincent, Infrared spectroscopy during electrocatalytic turnover reveals the Ni-L active site state during $\mathrm{H}_{2}$ oxidation by a NiFe hydrogenase., Angew. Chem. Int. Ed. Engl. 54 (2015) 7110-7113. doi 10. 1002/anie.201502338.

-• This article is the first demonstration of the potential of the use of the concomitant monitoring of catalytic activity using PFV and detection of IR spectra to show the catalytic relevance of the Ni-L state.

[33] J. A. Cracknell, K. A. Vincent, M. Ludwig, O. Lenz, B. Friedrich, F. A. Armstrong, Enzymatic oxidation of $\mathrm{H}_{2}$ in atmospheric $\mathrm{O}_{2}$ : The electrochemistry of energy generation from trace $\mathrm{H}_{2}$ by aerobic microorganisms, J. Am. Chem. Soc. (2007). doi $10.1021 / \mathrm{ja078299+.}$

[34] L. Lauterbach, J. Liu, M. Horch, P. Hummel, A. Schwarze, M. Haumann, K. A. Vincent, O. Lenz, I. Zebger, The hydrogenase subcomplex of the NAD+-reducing [NiFe] hydrogenase from Ralstonia eutropha - insights into catalysis and redox interconversions, Eur. J. Inorg. Chem. 2011 (2011) 1067-1079. doi 10.1002/ejic. 201001053.

[35] A. I. Yaropolov, A. A. Karyakin, S. D. Varfolomeev, I. V. Berezin, Mechanism of $\mathrm{H}_{2}$-electrooxidation with immobilized hydrogenase, Bioelectrochemistry and Bioenergetics 12 (1984) 267-277. doi 10.1016/0302-4598(84)87009-9.

[36] T. Kihara, X.-Y. Liu, C. Nakamura, K.-M. Park, S.-W. Han, D.-J. Qian, K. Kawasaki, N. A. Zorin, S. Yasuda, K. Hata, T. Wakayama, J. Miyake, Direct electron transfer to hydrogenase for catalytic hydrogen production using a singlewalled carbon nanotube forest, International Journal of Hydrogen Energy 36 (2011) 7523-7529. doi:10.1016/j.ijhydene.2011.03.135.

[37] A. A. Karyakin, S. V. Morozov, E. E. Karyakina, S. D. Varfolomeyev, N. A. Zorin, S. Cosnier, Hydrogen fuel electrode based on bioelectrocatalysis by the enzyme hydrogenase, Electrochemistry Communications 4 (2002) 417-420. doi:10.1016/ s1388-2481(02)00335-1. 
[38] A. A. Karyakin, S. V. Morozov, O. G. Voronin, N. A. Zorin, E. E. Karyakina, V. N. Fateyev, S. Cosnier, The limiting performance characteristics in bioelectrocatalysis of hydrogenase enzymes, Angew. Ch. Int. Ed. 46 (2007) 7244-7246. doi:10.1002/ anie.200701096.

[39] K. So, R. Hamamoto, R. Takeuchi, Y. Kitazumi, O. Shirai, R. Endo, H. Nishihara, Y. Higuchi, K. Kano, Bioelectrochemical analysis of thermodynamics of the catalytic cycle and kinetics of the oxidative inactivation of oxygen-tolerant [NiFe]hydrogenase, J. Electroanal. Chem. 766 (2016) 152-161. doi:10.1016/j.jelechem. 2016.02.009.

[40] Effects of mesoporous structures on direct electron transfer-type bioelectrocatalysis: Facts and simulation on a three-dimensional model of random orientation of enzymes, Electrochemistry, the Electrochemical Society of Japan 85 (2017) 82-87. doi:10.5796/electrochemistry.85.82

[41] C. Gutiérrez-Sánchez, D. Olea, M. Marques, V. M. Fernández, I. A. C. Pereira, M. Vélez, A. L. De Lacey, Oriented immobilization of a Membrane-Bound hydrogenase onto an electrode for direct electron transfer, Langmuir 27 (2011) 6449-6457. doi $10.1021 /$ la200141t

[42] O. Gutiérrez-Sanz, C. Tapia, M. C. Marques, S. Zacarias, M. Vélez, I. A. C. Pereira, A. L. De Lacey, Induction of a proton gradient across a Gold-Supported biomimetic membrane by electroenzymatic $\mathrm{H}_{2}$ oxidation, Angew. Chem. Int. Ed. 54 (2015) 2684-2687. doi:10.1002/anie.201411182.

[43] P. Ceccaldi, M. C. Marques, V. Fourmond, I. C. Pereira, C. Léger, Oxidative inactivation of NiFeSe hydrogenase, Chem. Commun. 51 (2015) 14223-14226. doi $10.1039 / \mathrm{c5cc05930e}$.

[44] A. Parkin, G. Goldet, C. Cavazza, J. C. Fontecilla-Camps, F. A. Armstrong, The difference a se makes? Oxygen-Tolerant hydrogen production by the [NiFeSe]hydrogenase from Desulfomicrobium baculatum, J. Am. Chem. Soc. 130 (2008) 13410-13416. doi $10.1021 / \mathrm{ja} 803657 \mathrm{~d}$.

[45] E. Reisner, D. J. Powell, C. Cavazza, J. C. Fontecilla-Camps, F. A. Armstrong, Visible Light-Driven $\mathrm{H}_{2}$ production by hydrogenases attached to Dye-Sensitized $\mathrm{TiO}_{2}$ nanoparticles, J. Am. Chem. Soc. 131 (2009) 18457-18466. doi:10.1021/ja907923r

[46] D. Mersch, C.-Y. Lee, J. Z. Zhang, K. Brinkert, J. C. Fontecilla-Camps, A. W. Rutherford, E. Reisner, Wiring of photosystem II to hydrogenase for photoelectrochemical water splitting, J. Am. Chem. Soc. 137 (2015) 8541-8549. doi:10.1021/ jacs.5b03737.

•• Here the authors describe a photoelectrochemical cell that is based on direct electron transfer. Photosystem II absorbs light and oxidizes water on onde electrode; a hydrogenase produces $\mathrm{H}_{2}$ on the other. The electron transport chain is simpler than the Natural "Z scheme" of photosynthesis, but the price to pay for having 
a single photosynthetic enzyme is the small bias that has to be applied to drive photoelectrolysis with this semiartificial system.

[47] C.-Y. Lee, H. S. Park, J. C. Fontecilla-Camps, E. Reisner, Photoelectrochemical $\mathrm{H}_{2}$ evolution with a hydrogenase immobilized on a $\mathrm{TiO}_{2}$-protected silicon electrode, Angew. Chem. Int. Ed. 55 (2016) 5971-5974. doi:10.1002/anie.201511822.

[48] S. Morra, F. Valetti, S. J. Sadeghi, P. W. King, T. Meyer, G. Gilardi, Direct electrochemistry of an [FeFe]-hydrogenase on a $\mathrm{TiO}_{2}$ electrode, Chem. Commun. 47 (2011) 10566-10568. doi:10.1039/c1cc14535e.

[49] M. Hambourger, M. Gervaldo, D. Svedruzic, P. W. King, D. Gust, M. Ghirardi, A. L. Moore, T. A. Moore, [FeFe]-Hydrogenase-Catalyzed $\mathrm{H}_{2}$ production in a photoelectrochemical biofuel cell, J. Am. Chem. Soc. 130 (2008) 2015-2022. doi $10.1021 / \mathrm{ja} 077691 \mathrm{k}$.

[50] C. Madden, M. D. Vaughn, I. Díez-Pérez, K. A. Brown, P. W. King, D. Gust, A. L. Moore, T. A. Moore, Catalytic turnover of [FeFe]-hydrogenase based on Single-Molecule imaging, J. Am. Chem. Soc. 134 (2012) 1577-1582. doi:10.1021/ ja207461t

-• Direct observation of the single enzyme distribution on the Au-SAM surface (Clostridium acetobutylicum) FeFe hydrogenase).

[51] T. J. McDonald, D. Svedruzic, Y.-H. Kim, J. L. Blackburn, S. B. Zhang, P. W. King, M. J. Heben, Wiring-Up hydrogenase with Single-Walled carbon nanotubes, Nano Lett. 7 (2007) 3528-3534. doi 10.1021/n1072319o.

[52] D. Svedružić, J. L. Blackburn, R. C. Tenent, J.-D. D. Rocha, T. B. Vinzant, M. J. Heben, P. W. King, High-performance hydrogen production and oxidation electrodes with hydrogenase supported on metallic single-wall carbon nanotube networks., J. Am. Chem. Soc. 133 (2011) 4299-4306. doi:10.1021/ja104785e.

[53] C. Baffert, M. Demuez, L. Cournac, B. Burlat, B. Guigliarelli, P. Bertrand, L. Girbal, C. Léger, Hydrogen-Activating enzymes: Activity does not correlate with oxygen sensitivity, Angew. Chem. Int. Ed. 47 (2008) 2052-2054. doi:10.1002/anie. 200704313

[54] G. Goldet, C. Brandmayr, S. T. Stripp, T. Happe, C. Cavazza, J. C. FontecillaCamps, F. A. Armstrong, Electrochemical kinetic investigations of the reactions of $[\mathrm{FeFe}]$-hydrogenases with carbon monoxide and oxygen: Comparing the importance of gas tunnels and Active-Site Electronic/Redox effects, J. Am. Chem. Soc. 131 (2009) 14979-14989. doi:10.1021/ja905388j.

[55] P.-P. Liebgott, F. Leroux, B. Burlat, S. Dementin, C. Baffert, T. Lautier, V. Fourmond, P. Ceccaldi, C. Cavazza, I. Meynial-Salles, P. Soucaille, J. C. FontecillaCamps, B. Guigliarelli, P. Bertrand, M. Rousset, C. Léger, Relating diffusion along the substrate tunnel and oxygen sensitivity in hydrogenase, Nat. Chem. Biol. 6 (2009) 63-70. doi $10.1038 /$ nchembio.276. 
[56] V. Fourmond, C. Greco, K. Sybirna, C. Baffert, P.-H. Wang, P. Ezanno, M. Montefiori, M. Bruschi, I. Meynial-Salles, P. Soucaille, J. Blumberger, H. Bottin, L. De Gioia, C. Léger, The oxidative inactivation of FeFe hydrogenase reveals the flexibility of the H-cluster, Nat. Chem. 6 (2014) 336-342. doi $10.1038 /$ nchem. 1892

[57] A. Kubas, C. Orain, D. De Sancho, L. Saujet, M. Sensi, C. Gauquelin, I. MeynialSalles, P. Soucaille, H. A. Bottin, C. Baffert, V. Fourmond, R. B. Best, J. Blumberger, C. Léger, Mechanism of $\mathrm{O}_{2}$ diffusion and reduction in FeFe hydrogenases, Nat. Chem. 9 (2017) 88-95. doi 10.1038/nchem. 2592.

-• This article is an illustration of the power of combining kinetic techniques from $\mathrm{PFV}$ and theoretical chemistry approaches, here to elucidate all steps in the reaction of $\mathrm{O}_{2}$ with $\mathrm{FeFe}$ hydrogenases.

[58] C. Baffert, K. Sybirna, P. Ezanno, T. Lautier, V. Hajj, I. Meynial-Salles, P. Soucaille, H. Bottin, C. Léger, Covalent attachment of FeFe hydrogenases to carbon electrodes for direct electron transfer, Anal. Chem. 84 (2012) 7999-8005. doi $10.1021 /$ ac301812s

[59] A. Adamska, A. Silakov, C. Lambertz, O. Rüdiger, T. Happe, E. Reijerse, W. Lubitz, Identification and characterization of the "Super-Reduced" state of the H-Cluster in $[\mathrm{FeFe}$ hydrogenase: A new building block for the catalytic cycle?, Angew. Chem. Int. Ed. 51 (2012) 11458-11462. doi:10.1002/anie.201204800

[60] C. Orain, L. Saujet, C. Gauquelin, P. Soucaille, I. Meynial-Salles, C. Baffert, V. Fourmond, H. Bottin, C. Léger, Electrochemical measurements of the kinetics of inhibition of two $\mathrm{FeFe}$ hydrogenases by $\mathrm{O}_{2}$ demonstrate that the reaction is partly reversible, J. Am. Chem. Soc. 137 (2015) 12580-12587. doi 10.1021/jacs.5b06934

[61] K. A. Brown, M. B. Wilker, M. Boehm, G. Dukovic, P. W. King, Characterization of photochemical processes for $\mathrm{H}_{2}$ production by CdS Nanorod-[FeFe] hydrogenase complexes, J. Am. Chem. Soc. 134 (2012) 5627-5636. doi:10.1021/ja2116348.

[62] J. K. Utterback, M. B. Wilker, K. A. Brown, P. W. King, J. D. Eaves, G. Dukovic, Competition between electron transfer, trapping, and recombination in CdS nanorod-hydrogenase complexes., Physical chemistry chemical physics : PCCP 17 (2015) 5538-5542. doi $10.1039 /$ c4cp05993j.

[63] M. B. Wilker, K. E. Shinopoulos, K. A. Brown, D. W. Mulder, P. W. King, G. Dukovic, Electron transfer kinetics in CdS nanorod-[FeFe]-hydrogenase complexes and implications for photochemical $\mathrm{H}_{2}$ generation., J. Am. Chem. Soc. 136 (2014) 4316-4324. doi $10.1021 / \mathrm{ja} 413001 \mathrm{p}$.

[64] K. A. Brown, S. Dayal, X. Ai, G. Rumbles, P. W. King, Controlled assembly of hydrogenase-CdTe nanocrystal hybrids for solar hydrogen production., J. Am. Chem. Soc. 132 (2010) 9672-9680. doi 10.1021/ja101031r. 
[65] K. A. Brown, Q. Song, D. W. Mulder, P. W. King, Diameter dependent electron transfer kinetics in semiconductor-enzyme complexes., ACS nano 8 (2014) 1079010798. doi $10.1021 / \mathrm{nn} 504561 \mathrm{v}$.

[66] Y. Zhao, N. C. Anderson, M. W. Ratzloff, D. W. Mulder, K. Zhu, J. A. Turner, N. R. Neale, P. W. King, H. M. Branz, Proton reduction using a Hydrogenase-Modified nanoporous black silicon photoelectrode., ACS applied materials \& interfaces 8 (2016) 14481-14487. doi 10.1021/acsami.6b00189

[67] S. Morra, F. Valetti, V. Sarasso, S. Castrignanò, S. J. Sadeghi, G. Gilardi, Hydrogen production at high faradaic efficiency by a bio-electrode based on $\mathrm{TiO}_{2}$ adsorption of a new [FeFe]-hydrogenase from Clostridium perfringens, Bioelectrochemistry 106 (2015) 258-262. doi:10.1016/j.bioelechem.2015.08.001.

[68] A. Parkin, C. Cavazza, J. C. Fontecilla-Camps, F. A. Armstrong, Electrochemical investigations of the interconversions between catalytic and inhibited states of the [FeFe]-hydrogenase from Desulfovibrio desulfuricans., J. Am. Chem. Soc. 128 (2006) 16808-16815. doi $10.1021 / \mathrm{ja064425i}$.

[69] H. Krassen, S. Stripp, G. von Abendroth, K. Ataka, T. Happe, J. Heberle, Immobilization of the [FeFe]-hydrogenase CrHydA1 on a gold electrode: Design of a catalytic surface for the production of molecular hydrogen, Journal of Biotechnology 142 (2009) 3-9. doi $10.1016 / \mathrm{j} \cdot$ jbiotec. 2009.01.018.

[70] C. Baffert, L. Bertini, T. Lautier, C. Greco, K. Sybirna, P. Ezanno, E. Etienne, P. Soucaille, P. Bertrand, H. Bottin, I. Meynial-Salles, L. De Gioia, C. Léger, CO disrupts the reduced h-cluster of FeFe hydrogenase. a combined DFT and protein film voltammetry study., J. Am. Chem. Soc. 133 (2011) 2096-2099. doi:10.1021/ ja110627b

[71] J. N. Butt, M. Filipiak, W. R. Hagen, Direct electrochemistry of Megasphaera elsdenii iron hydrogenase - definition of the enzyme's catalytic operating potential and quantitation of the catalytic behaviour over a continuous potential range 245 (1997) 116-122. doi:10.1111/j.1432-1033.1997.00116.x

[72] M. Sensi, C. Baffert, C. Greco, G. Caserta, C. Gauquelin, L. Saujet, M. Fontecave, S. Roy, V. Artero, P. Soucaille, I. Meynial-Salles, H. Bottin, L. de Gioia, V. Fourmond, C. Léger, L. Bertini, Reactivity of the excited states of the H-Cluster of FeFe hydrogenases, J. Am. Chem. Soc. 138 (2016) 13612-13618. doi $10.1021 /$ jacs.6b06603.

[73] P. Ceccaldi, K. Schuchmann, V. Muller, S. J. Elliott, The hydrogen dependent $\mathrm{CO}_{2}$ reductase: the first completely CO tolerant FeFe-hydrogenase, Energy Environ. Sci. 10 (2017) 503-508. doi:10.1039/c6ee02494g.

-• This article is one of the demonstrations that studying "non-standard" enzymes, here the FeFe hydrogenase module of the Hydrogen Dependent Carbon dioxide Reductase from Acetobacterium woodii, can reveal unusual properties, such as higher resistance to irreversible damage by $\mathrm{CO}$ in reducing conditions. 
[74] C. Blanford, F. Armstrong, The pyrolytic graphite surface as an enzyme substrate: microscopic and spectroscopic studies, Journal of Solid State Electrochemistry 10 (2006) 826-832. doi:10.1007/s10008-006-0183-2.

[75] J. C. Fontecilla-Camps, A. Volbeda, C. Cavazza, Y. Nicolet, Structure/function relationships of [NiFe]- and [FeFe]-hydrogenases., Chemical reviews 107 (2007) 42734303. doi $10.1021 / \operatorname{cr} 050195 z$.

[76] E. Lojou, Hydrogenases as catalysts for fuel cells: Strategies for efficient immobilization at electrode interfaces, Electrochimica Acta 56 (2011) 10385-10397. doi: $10.1016 / \mathrm{j}$.electacta.2011.03.002.

[77] P. W. King, Designing interfaces of hydrogenase-nanomaterial hybrids for efficient solar conversion., Biochimica et biophysica acta 1827 (2013) 949-957. doi:10.1016/ j.bbabio.2013.03.006

[78] P. O. Saboe, E. Conte, M. Farell, G. C. Bazan, M. Kumar, Biomimetic and bioinspired approaches for wiring enzymes to electrode interfaces, Energy Environ. Sci. 10 (2017) 14-42. doi $10.1039 / \mathrm{c} 6 \mathrm{ee} 02801 \mathrm{~b}$.

[79] V. Radu, S. Frielingsdorf, S. D. Evans, O. Lenz, L. J. C. Jeuken, Enhanced OxygenTolerance of the full heterotrimeric Membrane-Bound [NiFe]-hydrogenase of ralstonia eutropha, J. Am. Chem. Soc. 136 (2014) 8512-8515. doi 10.1021/ja503138p.

-• The oligomeric form of Ralstonia eutropha membrane bound hydrogenase embedded in a planar bilayer lipid membranes tethered to a gold electrode. Electron transfer is mediated by the quinone pool in the membrane. The results of the electrochemical investigation contrast with those obtained with the same enzyme undergoing direct electron transfer with a graphite electrode. In particular, the authors observe a greater resistance to oxidative inactivation.

[80] V. Radu, S. Frielingsdorf, O. Lenz, L. J. C. Jeuken, Reactivation from the Ni-B state in $[\mathrm{NiFe}]$ hydrogenase of ralstonia eutropha is controlled by reduction of the superoxidised proximal cluster, Chem. Commun. 52 (2016) 2632-2635. doi $10.1039 /$ c5cc10382g.

[81] L. J. Jeuken, Structure and modification of electrode materials for protein electrochemistry., Advances in biochemical engineering/biotechnology (2016). doi 10 . 1007/10_2015_5011.

[82] J. Esselborn, C. Lambertz, A. Adamska-Venkatesh, T. Simmons, G. Berggren, J. Noth, J. Siebel, A. Hemschemeier, V. Artero, E. Reijerse, M. Fontecave, W. Lubitz, T. Happe, Spontaneous activation of $[\mathrm{FeFe}]-$ hydrogenases by an inorganic [2Fe] active site mimic., Nature chemical biology 9 (2013) 607-609. doi:10.1038/ nchembio.1311.

[83] N. Khanna, C. Esmieu, L. S. Meszaros, P. Lindblad, G. Berggren, In vivo activation of an $[\mathrm{FeFe}]$ hydrogenase using synthetic cofactors, Energy Environ. Sci. (2017). doi: $10.1039 / \mathrm{c} 7 \mathrm{ee} 00135 \mathrm{e}$. 
[84] C. F. Megarity, J. Esselborn, S. V. Hexter, F. Wittkamp, U.-P. Apfel, T. Happe, F. A. Armstrong, Electrochemical investigations of the mechanism of assembly of the Active-Site H-Cluster of [FeFe]-hydrogenases, J. Am. Chem. Soc. 138 (2016) 15227-15233. doi $10.1021 /$ jacs .6b09366.

-• A very original and insightful electrochemical study of $\mathrm{H}$ cluster insertion in $\mathrm{FeFe}$ hydrogenase.

[85] L. Zhang, R. Miranda-Castro, C. Stines-Chaumeil, N. Mano, G. Xu, F. Mavré, B. Limoges, Heterogeneous reconstitution of the PQQ-dependent glucose dehydrogenase immobilized on an electrode: A sensitive strategy for PQQ detection down to picomolar levels, Anal. Chem. 86 (2014) 2257-2267. doi:10.1021/ac500142e.

[86] C. Léger, A. K. Jones, S. P. J. Albracht, F. A. Armstrong, Effect of a dispersion of interfacial electron transfer rates on steady state catalytic electron transport in [NiFe]-hydrogenase and other enzymes, J. Phys. Chem. B 106 (2002) 13058-13063. doi:10.1021/jp0265687.

[87] C. Léger, S. Dementin, P. Bertrand, M. Rousset, B. Guigliarelli, Inhibition and aerobic inactivation kinetics of Desulfovibrio fructosovorans $\mathrm{NiFe}$ hydrogenase studied by protein film voltammetry, J. Am. Chem. Soc. 126 (2004) 12162-12172. doi $10.1021 / \mathrm{ja046548d}$.

[88] V. Hajj, C. Baffert, K. Sybirna, I. Meynial-Salles, P. Soucaille, H. Bottin, V. Fourmond, C. Leger, FeFe hydrogenase reductive inactivation and implication for catalysis, Energy Environ. Sci. 7 (2014) 715-719. doi 10.1039/c3ee42075b.

[89] V. Fourmond, C. Baffert, K. Sybirna, T. Lautier, A. Abou Hamdan, S. Dementin, P. Soucaille, I. Meynial-Salles, H. Bottin, C. Léger, Steady-State catalytic WaveShapes for 2-electron reversible electrocatalysts and enzymes, J. Am. Chem. Soc. 135 (2013) 3926-3938. doi:10.1021/ja311607s

[90] V. Fourmond, C. Léger, Modelling the voltammetry of adsorbed enzymes and molecular catalysts, Curr. Op. Electrochem. 1 (2017) 110-120. doi:10.1016/j.coelec. 2016.11 .002 .

- Comprehensive description of all models proposed to quantitatively interpret the voltammetry of adsorbed enzymes, including hydrogenases.

[91] A. Cornish-Bowden, J. Wiley, Fundamentals of enzyme kinetics, Wiley-Blackwell, 2014.

- A rare textbook to debunk the idea that catalysts must work both ways: "some enzymes are much more effective catalysts for one direction than the other, [although] even after a thorough discussion of this type of behavior [in the 1970's] many biochemists remain rather uneasy about it, suspecting that it may violate the laws of thermodynamics". 
[92] S. Gentil, N. Lalaoui, A. Dutta, Y. Nedellec, S. Cosnier, W. J. Shaw, V. Artero, A. Le Goff, Carbon-Nanotube-supported Bio-Inspired nickel catalyst and its integration in hybrid Hydrogen/Air fuel cells, Angew. Chem. 129 (2017) 1871-1875. doi 10.1002 /ange.201611532.

[93] P. Raleiras, N. Khanna, H. Miranda, L. S. Meszaros, H. Krassen, F. Ho, N. Battchikova, E.-M. Aro, A. Magnuson, P. Lindblad, S. Styring, Turning around the electron flow in an uptake hydrogenase. EPR spectroscopy and in vivo activity of a designed mutant in HupSL from Nostoc punctiforme, Energy Environ. Sci. 9 (2016) 581-594. doi:10.1039/c5ee02694f.

[94] C. Léger, P. Bertrand, Direct electrochemistry of redox enzymes as a tool for mechanistic studies, Chem. Rev. 108 (2008) 2379-2438. doi 10.1021/cr0680742.

[95] C. Léger, A. K. Jones, W. Roseboom, S. P. Albracht, F. A. Armstrong, Enzyme electrokinetics: hydrogen evolution and oxidation by allochromatium vinosum [NiFe]hydrogenase., Biochemistry 41 (2002) 15736-15746. doi 10.1021/bi026586e.

[96] V. Fourmond, C. Baffert, K. Sybirna, S. Dementin, A. Abou-Hamdan, I. MeynialSalles, P. Soucaille, H. Bottin, C. Leger, The mechanism of inhibition by $\mathrm{H}_{2}$ of $\mathrm{H}_{2}$-evolution by hydrogenases, Chem. Commun. 49 (2013) 6840-6842. doi $10.1039 /$ c3cc43297a.

[97] S. V. Hexter, F. Grey, T. Happe, V. Climent, F. A. Armstrong, Electrocatalytic mechanism of reversible hydrogen cycling by enzymes and distinctions between the major classes of hydrogenases., Proc. Natl. Acad. Sc. USA 109 (2012) 11516-11521. doi $10.1073 /$ pnas.1204770109.

[98] B. J. Murphy, F. Sargent, F. A. Armstrong, Transforming an oxygen-tolerant [NiFe] uptake hydrogenase into a proficient, reversible hydrogen producer, Energy Environ. Sci. 7 (2014) 1426-1433. doi $10.1039 /$ c3ee43652g.

[99] C. Léger, F. Lederer, B. Guigliarelli, P. Bertrand, Electron flow in multicenter enzymes: Theory, applications, and consequences on the natural design of redox chains, J. Am. Chem. Soc. 128 (2006) 180-187. doi:10.1021/ja055275z.

[100] C. Wombwell, C. A. Caputo, E. Reisner, [NiFeSe]-hydrogenase chemistry., Accounts of chemical research 48 (2015) 2858-2865. doi 10.1021/acs.accounts.5b00326

[101] L. A. Flanagan, A. Parkin, Electrochemical insights into the mechanism of NiFe membrane-bound hydrogenases., Biochem. Soc. Trans. 44 (2016) 315-328. doi 10. 1042/BST20150201.

[102] S. Dementin, F. Leroux, L. Cournac, A. L. Lacey, A. Volbeda, C. Léger, B. Burlat, N. Martinez, S. Champ, L. Martin, O. Sanganas, M. Haumann, V. M. Fernández, B. Guigliarelli, J. C. Fontecilla-Camps, M. Rousset, Introduction of methionines in the gas channel makes [NiFe] hydrogenase Aero-Tolerant, J. Am. Chem. Soc. 131 (2009) 10156-10164. doi $10.1021 /$ ja9018258 
[103] P.-P. Liebgott, A. L. de Lacey, B. Burlat, L. Cournac, P. Richaud, M. Brugna, V. M. Fernandez, B. Guigliarelli, M. Rousset, C. Léger, S. Dementin, Original design of an Oxygen-Tolerant [NiFe] hydrogenase: Major effect of a Valine-to-Cysteine mutation near the active site, J. Am. Chem. Soc. 133 (2011) 986-997. doi:10.1021/ja108787s

[104] A. Abou Hamdan, S. Dementin, P.-P. Liebgott, O. Gutierrez-Sanz, P. Richaud, A. L. De Lacey, M. Rousset, P. Bertrand, L. Cournac, C. Léger, Understanding and tuning the catalytic bias of hydrogenase, J. Am. Chem. Soc. 134 (2012) 8368-8371. doi:10.1021/ja301802r

[105] S. Dementin, V. Belle, P. Bertrand, B. Guigliarelli, G. Adryanczyk-Perrier, A. L. De Lacey, V. M. Fernandez, M. Rousset, C. Léger, Changing the ligation of the distal [4Fe4S] cluster in NiFe hydrogenase impairs inter- and intramolecular electron transfers, J. Am. Chem. Soc. 128 (2006) 5209-5218. doi:10.1021/ja060233b

[106] L. A. Flanagan, J. J. Wright, M. M. Roessler, J. W. Moir, A. Parkin, Reengineering a NiFe hydrogenase to increase the $\mathrm{H}_{2}$ production bias while maintaining native levels of $\mathrm{O}_{2}$ tolerance, Chem. Commun. 52 (2016) 9133-9136. doi $10.1039 / \mathrm{c} 6 \mathrm{cc} 00515 \mathrm{~b}$.

[107] H. Adamson, M. Robinson, J. J. Wright, L. A. Flanagan, J. Walton, D. Elton, D. J. Gavaghan, A. M. Bond, M. M. Roessler, A. Parkin, Re-tuning the catalytic bias and overpotential of a [NiFe]-hydrogenase via a single amino acid exchange at the electron entry/exit site, J. Am. Chem. Soc. (2017). doi 10.1021/jacs.7b03611.

- Fourier transformed alternating current voltammetry is used to detect and measure the potential of the distal FeS cluster in E. coli hydrogenase.

[108] A. K. Jones, S. E. Lamle, H. R. Pershad, K. A. Vincent, S. P. Albracht, F. A. Armstrong, Enzyme electrokinetics: electrochemical studies of the anaerobic interconversions between active and inactive states of allochromatium vinosum [NiFe]hydrogenase., J. Am. Chem. Soc. 125 (2003) 8505-8514. doi 10.1021/ja035296y.

[109] C. Greco, V. Fourmond, C. Baffert, P.-h. Wang, S. Dementin, P. Bertrand, M. Bruschi, J. Blumberger, L. de Gioia, C. Leger, Combining experimental and theoretical methods to learn about the reactivity of gas-processing metalloenzymes, Energy Environ. Sci. 7 (2014) 3543-3573. doi 10.1039/c4ee01848f

[110] K. Chen, J. Hirst, R. Camba, C. A. Bonagura, C. D. Stout, B. K. Burgess, F. A. Armstrong, Atomically defined mechanism for electron-coupled proton transfer to a buried redox centre in a protein, Nature 405 (2000) 814-817. doi $10.1038 / 35015610$

[111] A. F. Wait, C. Brandmayr, S. T. Stripp, C. Cavazza, J. C. Fontecilla-Camps, T. Happe, F. A. Armstrong, Formaldehyde - A rapid and reversible inhibitor of hydrogen production by [FeFe]-hydrogenases, J. Am. Chem. Soc. 133 (2011) 12821285. doi $10.1021 / \mathrm{ja110103p}$. 
[112] C. E. Foster, T. Krämer, A. F. Wait, A. Parkin, D. P. Jennings, T. Happe, J. E. McGrady, F. A. Armstrong, Inhibition of [FeFe]-hydrogenases by formaldehyde and wider mechanistic implications for biohydrogen activation, J. Am. Chem. Soc. 134 (2012) 7553-7557. doi $10.1021 / \mathrm{ja302096r}$

[113] A. Bachmeier, J. Esselborn, S. V. Hexter, T. Krämer, K. Klein, T. Happe, J. E. McGrady, W. K. Myers, F. A. Armstrong, How formaldehyde inhibits hydrogen evolution by [FeFe]-hydrogenases: Determination by ${ }^{13} \mathrm{C}$ ENDOR of direct $\mathrm{Fe}-\mathrm{C}$ coordination and order of electron and proton transfers, J. Am. Chem. Soc. 137 (2015) 5381-5389. doi $10.1021 / \mathrm{ja} 513074 \mathrm{~m}$.

[114] F. Leroux, S. Dementin, B. Burlat, L. Cournac, A. Volbeda, S. Champ, L. Martin, B. Guigliarelli, P. Bertrand, J. Fontecilla-Camps, M. Rousset, C. Léger, Experimental approaches to kinetics of gas diffusion in hydrogenase, Proc. Natl. Acad. Sc. USA 105 (2008) 11188-11193. doi:10.1073/pnas.0803689105.

[115] P.-H. Wang, J. Blumberger, Mechanistic insight into the blocking of CO diffusion in [NiFe]-hydrogenase mutants through multiscale simulation. 109 (2012) 6399-6404. doi:10.1073/pnas.1121176109.

[116] D. Millo, P. Hildebrandt, M.-E. Pandelia, W. Lubitz, I. Zebger, SEIRA spectroscopy of the electrochemical activation of an immobilized [NiFe] hydrogenase under turnover and Non-Turnover conditions, Angew. Chem. Int. Ed. 50 (2011) 2632-2634. doi:10.1002/anie.201006646.

[117] M. Sezer, D. Millo, I. M. Weidinger, I. Zebger, P. Hildebrandt, Analyzing the catalytic processes of immobilized redox enzymes by vibrational spectroscopies., IUBMB life 64 (2012) 455-464. doi:10.1002/iub.1020.

[118] P. A. Ash, R. Hidalgo, K. A. Vincent, Proton transfer in the catalytic cycle of [NiFe] hydrogenases: Insight from vibrational spectroscopy., ACS Catal 7 (2017) 2471-2485. doi:10.1021/acscatal.6b03182.

[119] B. J. Murphy, R. Hidalgo, M. M. Roessler, R. M. Evans, P. A. Ash, W. K. Myers, K. A. Vincent, F. A. Armstrong, Discovery of dark pH-dependent $\mathrm{H}^{+}$migration in a [NiFe]-hydrogenase and its mechanistic relevance: Mobilizing the hydrido ligand of the Ni-C intermediate, J. Am. Chem. Soc. 137 (2015) 8484-8489. doi:10.1021/ jacs.5b03182.

[120] P. A. Ash, J. Liu, N. Coutard, N. Heidary, M. Horch, I. Gudim, T. Simler, I. Zebger, O. Lenz, K. A. Vincent, Electrochemical and infrared spectroscopic studies provide insight into reactions of the NiFe regulatory hydrogenase from Ralstonia eutropha with $\mathrm{O}_{2}$ and co, J. Phys. Chem. B 119 (2015) 13807-13815. doi:10.1021/acs.jpcb. $5 \mathrm{~b} 04164$ 
[121] W. Roseboom, A. De Lacey, V. Fernandez, Hatchikian, S. Albracht, The active site of the [FeFe]-hydrogenase from Desulfovibrio desulfuricans. II. redox properties, light sensitivity and CO-ligand exchange as observed by infrared spectroscopy, Journal of Biological Inorganic Chemistry 11 (2006) 102-118. doi 10. 1007/s00775-005-0040-2.

[122] P. Rodríguez-Maciá, J. A. Birrell, W. Lubitz, O. Rüdiger, Electrochemical investigations on the inactivation of the [FeFe] hydrogenase from desulfovibrio desulfuricans by $\mathrm{O}_{2}$ or light under Hydrogen-Producing conditions, ChemPlusChem 82 (2017) 540-545. doi:10.1002/cplu.201600508

[123] M. Sensi, C. Baffert, L. Fradale, C. Gauquelin, P. Soucaille, I. Meynial-Salles, H. Bottin, L. de Gioia, M. Bruschi, V. Fourmond, C. Léger, L. Bertini, Photoinhibition of FeFe hydrogenase, submitted (2017).

-• The comparison herein of the avalaible data show that not all FeFe hydrogenases can actually be combined with photosensitizers that utilise the solar spectrum: further investigations of the compatibility of hydrogenases or hydrogenase mimics with light-harvesting systems should also consider the possibility of irreversible photoinhibition.

[124] A. Ciaccafava, C. Hamon, P. Infossi, V. Marchi, M.-T. Giudici-Orticoni, E. Lojou, Light-induced reactivation of $\mathrm{O}_{2}$-tolerant membrane-bound [Ni-Fe] hydrogenase from the hyperthermophilic bacterium Aquifex aeolicus under turnover conditions, Phys. Chem. Chem. Phys. 15 (2013) 16463-16467. doi:10.1039/c3cp52596a.

-• This article demonstrates that purple light activates the oxidized, inactive forms of an $\mathrm{O}_{2}$-tolerant $\mathrm{NiFe}$ hydrogenase.

[125] M. Hambourger, G. F. Moore, D. M. Kramer, D. Gust, A. L. Moore, T. A. Moore, Biology and technology for photochemical fuel production, Chem. Soc. Rev. 38 (2009) 25-35. doi 10.1039/b800582f

[126] E. Reisner, Solar hydrogen evolution with hydrogenases: From natural to hybrid systems, Eur. J. Inorg. Chem. 2011 (2011) 1005-1016. doi:10.1002/ejic. 201000986.

[127] T. W. Woolerton, S. Sheard, Y. S. Chaudhary, F. A. Armstrong, Enzymes and bio-inspired electrocatalysts in solar fuel devices, Energy Environ. Sci. 5 (2012) 7470-7490. doi:10.1039/c2ee21471g

[128] H. A. Reeve, P. A. Ash, H. Park, A. Huang, M. Posidias, C. Tomlinson, O. Lenz, K. A. Vincent, Enzymes as modular catalysts for redox half-reactions in $\mathrm{H}_{2}$-powered chemical synthesis: from biology to technology, Biochemical Journal 474 (2017) 215230. doi:10.1042/bcj20160513.

-• A very recent review that describes the applications of hydrogenases. See also refs. [77, 125-127]. 